\title{
Development of Learning Tools Based on Mind Mapping Worksheet for Improving Stundents' Creative Thinking Skills on Cell Material
}

\begin{tabular}{|c|c|}
\hline \multicolumn{2}{|c|}{$\begin{array}{c}\text { Ainul Badriyah }{ }^{1} \text {, Sri Poedjiastoeti }{ }^{2}, \text { Yuliani }^{3} \\
\text { 1,2,3Universitas Negeri Surabaya, Surabaya, Indonesia }\end{array}$} \\
\hline 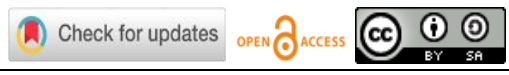 & DOI : https://doi.org/10.46245/ijorer.v2i5.154 \\
\hline Sections Info & ABSTRACT \\
\hline $\begin{array}{l}\text { Article history: } \\
\text { Submitted: August 21, } 2021 \\
\text { Final Revised: September 20, } 2021 \\
\text { Accepted: September 28, 2021 } \\
\text { Published: September 30, } 2021 \\
\end{array}$ & $\begin{array}{l}\text { Life skills-based education is an important tool to face today's global } \\
\text { demands, one of which is creative thinking skills. This study aims to } \\
\text { determine the feasibility of learning tools based on mind mapping } \\
\text { worksheet to practice creative thinking skills for class XI MIPA on cell } \\
\text { material, which are viewed in terms of (1) validity, (2) practicality and (3) }\end{array}$ \\
\hline $\begin{array}{l}\text { Keywords: } \\
\text { worksheet } \\
\text { mind mapping } \\
\text { creative thinking skills }\end{array}$ & $\begin{array}{l}\text { LKDP and tests of creative thinking skills. The mind mapping worksheet } \\
\text { that was trained included indicators of creative thinking skills, fluency, } \\
\text { flexibility, originality and elaboration, which were tested on } 23 \text { students }\end{array}$ \\
\hline 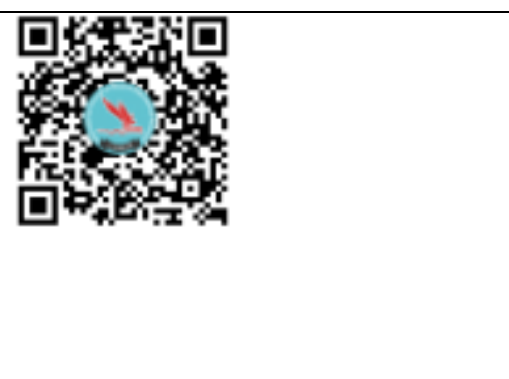 & $\begin{array}{l}\text { of Class XI MIPA SMA Al-Islam Krian. This study used a } 4 \mathrm{D} \text { design with } \\
\text { one group pretest-posttest design, the data obtained were analyzed } \\
\text { descriptively. The results of the validity of the device get mode } 4 \text { with a } \\
\text { very valid category. The results of the practicality of the device were } \\
\text { carried out with mode } 4 \text { in the very good category. The effectiveness of } \\
\text { the device is based on the average N-gain score ranging from } 0.5 \text { to } 0.92 \text {. } \\
\text { The result of students' mastery of the concept of the material is } 86.3 \text { in the } \\
\text { complete category. Students' responses to the four LKPD mind mapping } \\
\text { developed were } 81 \% \text { in the positive category. }\end{array}$ \\
\hline
\end{tabular}

\section{INTRODUCTION}

Life skills-based education, one of which is creative thinking skills, is an important means to prepare for global demands. A proper learning tool both theoretically and empirically is needed to train creative thinking skills. Creativity is a product of creative thinking. Creative thinking skills through mind mapping can assemble mental abilities that involve cognitive processes, personality characteristics, and environmental variables, as well as the interaction of other components to generate ideas that are useful in problem solving (Eratay, 2017). Learning through mind mapping strategies makes a positive contribution to the development of math and science skills (Polat et al., 2017). Mind mapping strategies in learning can activate the right and left brain lobes, meaningful and efficient learning, facilitate memory, become a form of practical presentation that is prepared in a short time, and increase students' interest, attention and motivation (Erdem, 2017).

The concept of the cell requires a constructed understanding of the process of assimilation to equilibration through a molecular approach to life phenomena related to the structure, function, and interrelationships between cell structure and function (Heni et al., 2017) Very broad cell material requires students to understand all learning content. A creative thinking learning device is needed to make it easier for students to 
Development of Learning Tools Based on Mind Mapping Worksheet for Improving Stundents' Creative Thinking Skills on Cell Material

learn cell material. Challenging activities will encourage students to develop creative thinking skills fluency, flexibility, originality or elaboration to practice understanding, reasoning (reasoning), application of concepts and analytical thinking to solve problems. Based on the learning experience they have, students do not only master one ability but also three domains, namely; cognitive, affective, and psychomotor. The Student Worksheet (LKPD) is one of the teaching materials that has many advantages, namely making it easier for educators to carry out learning and students will learn independently and learn to understand and carry out written assignments (Marshel et al., 2020). LKPD is very effective for developing thinking skills and indicators of selfachievement (Susantini et al., 2016). Field data from the 2019 National High School/MA level UNBK results at the cell material amounted to $30.56 \%$ and at the Al-Islam Krian High School education unit level of 35.71, it was still far from the minimum absorption capacity of $55 \%$. The results of student and teacher interviews through the instruments provided were $71.2 \%$ of students did not understand the cell material, and so far LKPD as one of the teaching materials used in MGPS-centered learning and publishers, so that access to students' creative thinking skills has not been implemented.

The results of previous research stated that student learning outcomes through the application of LKPD mind mapping on growth and development materials were $85 \%$ with an $\mathrm{N}$-gain of 0.72 , and flexible thinking creative thinking indicators (flexible thinking) of $82.5 \%$ (Setyawan, 2019). The use of Mind mapping through digital applications can help students visualize the structure and functional processes that occur in cells and connect between topics they learn in cell biology (Yeong, 2013). The effectiveness of genetics worksheets to train creative thinking skills using one group pre-post test design shows the development of students' creative thinking skills (Susanti et al., 2016). Mind mapping method in learning the human reproductive system in junior high school students, improves student learning outcomes and student responses are very helpful in remembering for understanding Latin languages and new concepts in the material (Dewi, 2019).

Based on the background of the problems that have been described then the general problem formulation in this research is: "How is the Feasibility of Mind Mapping Worksheet Based Learning Tools to Practice Creative Thinking Skills for Class XI MIPA on Cell Materials?", described through the following research questions; (1) How is the validity of the learning tools developed in terms of the presentation structure, material aspects, conformity with mind mapping and aspects of the scope of creative thinking skills?; (2) How is the practicality of the developed device in terms of its implementation through student activities during the learning process?; (3) How is the effectiveness of the device in terms of the results of creative thinking skills and student responses?.

\section{RESEARCH METHOD}

This research is development research using the $4 \mathrm{D}$ model. This research was carried out from Januari to Juni 2021. The development stage was carried out at the Postgraduate UNESA (Figure 1). 
Development of Learning Tools Based on Mind Mapping Worksheet for Improving Stundents' Creative Thinking Skills on Cell Material

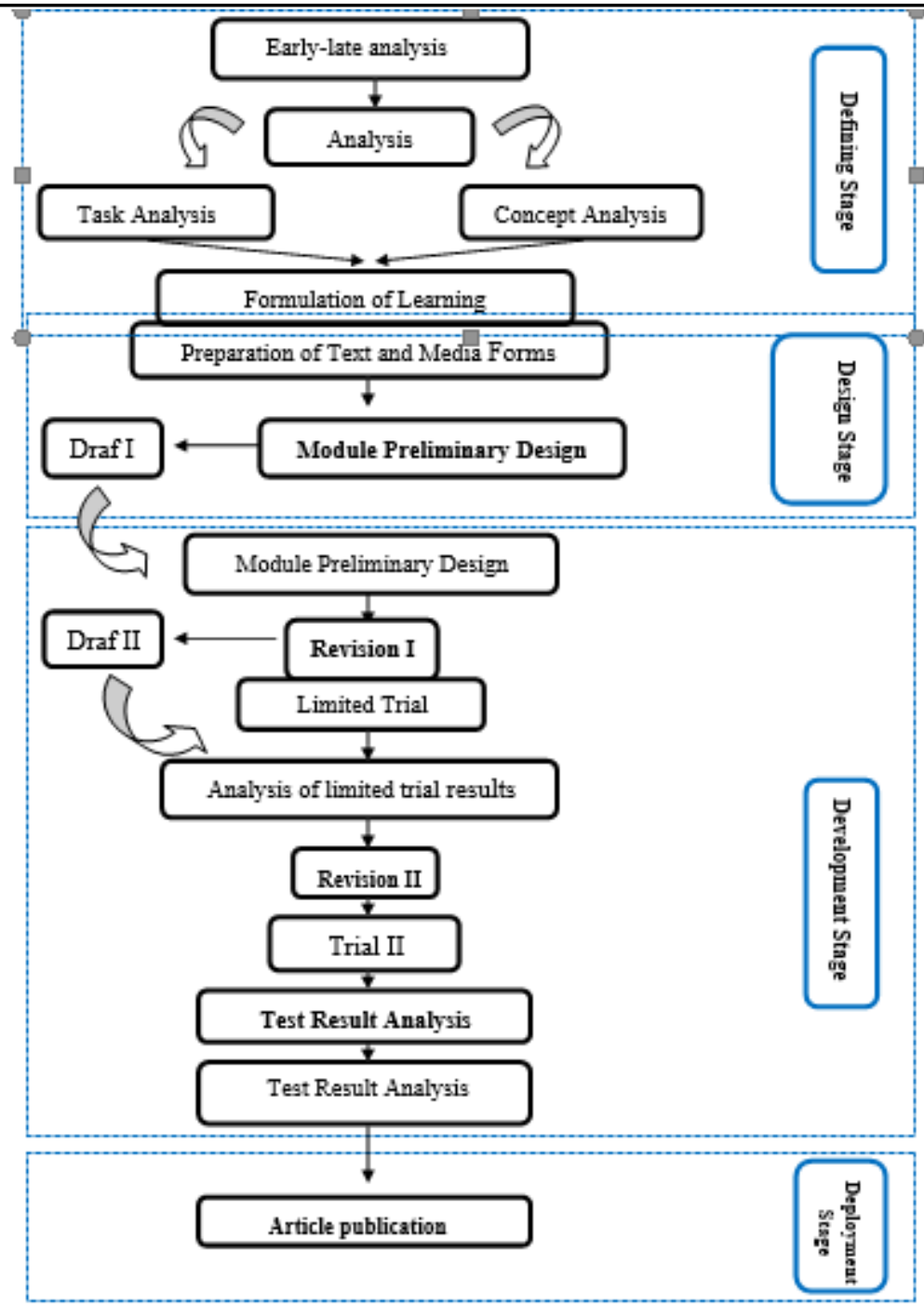

Figure 1. 4-D development model.

\section{Sample / Participants / Group}

The research subjects are learning tools, especially mind mapping worksheets to train students' creative thinking skills on cell material, the data sources for the trial are 23 students of class XI SMA Al-islam Krian Class XI Science for the academic year 2020/2021 with heterogeneous abilities

\section{Instrument and Procedures}

The research design used, namely the One Group Pretest-Posttest Design (Sugiono, 2018), is described as follows:

$$
\mathrm{O}_{1} \longrightarrow \mathrm{X} \longrightarrow \mathrm{O}_{2}
$$

Information :

O1 : Pretest value before being given treatment

$\mathrm{X}$ : Learning using mind mapping worksheet

$\mathrm{O} 2$ : Pretest value after being given treatment 
Development of Learning Tools Based on Mind Mapping Worksheet for Improving Stundents' Creative Thinking Skills on Cell Material

The research instruments used in this study were (1) device validation sheets, (2) device implementation sheets, (3) creative thinking skills evaluation tests, and (4) student response questionnaires to mind mapping worksheets. The results of the data obtained in the form of a score from each aspect of the research that has been determined. Each aspect is assessed based on the Linkert scale with intervals of 1-4 as presented in Table 1

Table 1. Likert scale criteria.

\begin{tabular}{cc}
\hline Rating & Scale Value \\
\hline 1 & Not good \\
2 & Pretty good \\
3 & Good \\
4 & Very good \\
\hline & (Adapted from Riduwan, 2013)
\end{tabular}

\section{Data Analysis}

Validity analysis

Device validity data analysis techniques learning includes syllabus, lesson plans, LKPD mind mapping and creative thinking skills tests using qualitative descriptive. The resulting mode values are interpreted in Table 2 below

Table 2. Interpretation of validation analysis score.

\begin{tabular}{cc}
\hline Rating & Scale Value \\
\hline 1 & Very Valid \\
2 & Valid \\
3 & Quite Valid \\
4 & Less Valid \\
\hline & (Adapted from Riduwan, 2013)
\end{tabular}

\section{Practical analysis}

The analysis of the practicality of learning devices is the result of an observer's assessment of the activities of students in learning. The mode value of each observation component is interpreted in Table 3 below

Table 3. Interpretation of validation analysis score.

\begin{tabular}{cc}
\hline Rating & Scale Value \\
\hline 1 & Less Practical \\
2 & Practical enough \\
3 & Practical \\
4 & Very Practical \\
\hline & (Adapted from Riduwan, 2013)
\end{tabular}

\section{Effectiveness analysis}

Creative thinking skill scores were obtained based on the data from the students' pretest and posttest results, using the equation formula:

$$
\text { Nílai Ketuntasan Individu }=\frac{\sum \text { skoryang diperoleh }}{\sum \text { skor maksimum }} \mathbf{x} 100
$$


Development of Learning Tools Based on Mind Mapping Worksheet for Improving Stundents' Creative Thinking Skills on Cell Material

Completeness is said to be good based on indicators if it gets a percentage of $\geq 75 \%$. The data is then analyzed to determine the improvement of student's initial abilities before and after learning. This increase is known through N-Gain analysis, then compared with categories by Hake (1999) namely normalized NGain, namely the comparison of the actual N-Gain score with the maximum NGain score. This can be expressed by the formula :

$$
<\mathbf{g}>=\frac{\%<S f>-\%<S i>}{\%<S \text { maks }>-\%<S i>} \times 100 \%
$$

Table 4. Normalized N-gain criteria.

\begin{tabular}{cc}
\hline Normalized N-Gain Range & N-Gain Criteria \\
\hline $\mathrm{g}<0,30$ & Low \\
$0,30 \leq \mathrm{g} \leq 0,7$ & Average \\
$\mathrm{g}>0,70$ & High \\
\hline
\end{tabular}

(Hake, 1999)

The effect of applying mind mapping worksheet to train students' creative thinking skills and mastery of concepts is carried out by parametric statistical analysis using SPSS 25.0 for windows, taking into account some assumptions that population size testing through sample data that is, the data to be analyzed must be distributed normal and using data from two or more groups homogeneous (Sugiyono, 2014) as follows. Analysis of the effectiveness of the developed tools include:

a. Kolmogorov Smirnov normality test

The normality test aims to determine whether the residuals are normally distributed or not by using the Kolmogorov-Smirnov test at a significance level of $=0.05$ (2tailed). The basis for decision making is as follows;

If the value of Sig (2-tailed) $>0.05$ then the data is normally distributed.

If the value of Sig $(2$-tailed) $<0.05$, then the data is not normally distributed.

b. Levene homogeneity test

The homogeneity test aims to determine the test sample has the same variance, namely by using the Levene test at a significance level of $=0.05$ (2-tailed). The basis for decision making is as follows:

If the value of Sig (2-tailed) $>0.05$ then the data is homogeneous

If the value of $\operatorname{Sig}$ (2-tailed) $<0.05$ then the data is not homogeneous.

c. Paired t-test

Paired t-test to find out whether there is a difference in the average of two paired samples (students' pretest results as data before treatment and students' posttest results as data after treatment). Paired t-test uses $n-1$ degrees of freedom, where $n$ is the number of samples with a significance level of $=0.05$ (2-tailed). The basis for decision making is as follows;

If the value of Sig (2-tailed) $<0.05$, then there is a significant difference between learning outcomes in pretest and posttest data.

If the value of Sig (2-tailed) > 0.05, then there is no significant difference between learning outcomes in pretest and posttest data.

(Santoso, 2014) 


\section{RESULTS AND DISCUSSION}

The developed mind mapping worksheet validation includes; (1) formative requirements include, among others, clarity and completeness of identity, suitability of LKPD, materials, models and learning objectives. (2) the didactic conditions in it contain the appropriateness of the content and the correctness of the language. (3) technical requirements. The level of validity (feasibility) of the LKPD mind mapping of the three validators is presented in Table 6 below;

Table 6. Mind mapping worksheet validation results.

No. Aspects of assessment Mind Mapping Worksheet

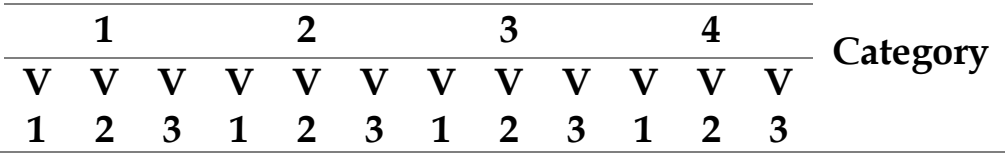

\section{Formative Conditions}

\section{A Identity clarity and completeness}

1. Include name and education unit

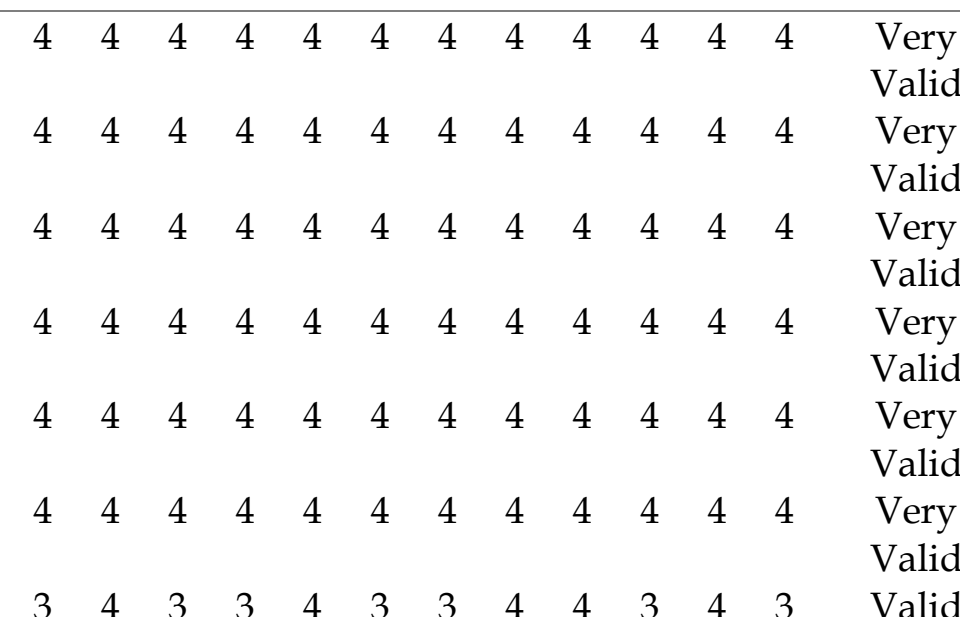

7. Effectiveness of time allocated to achieve goals

8. Allocated time efficiency

9. Clarity of Formulation of Indicators and Objectives with $\begin{array}{lllllllllllll}3 & 4 & 3 & 3 & 4 & 3 & 4 & 4 & 3 & 3 & 4 & 3 & \text { Valid }\end{array}$ KD

10. The elaboration of competency achievement indicators refers to basic competencies

11. The elaboration of learning objectives refers to indicators of $\begin{array}{lllllllllllll}3 & 4 & 4 & 3 & 4 & 4 & 4 & 4 & 4 & 3 & 4 & 4 & \text { Very }\end{array}$

Valid competency achievement

$\begin{array}{lllllllllllll}3 & 4 & 4 & 3 & 4 & 4 & 4 & 4 & 4 & 3 & 4 & 4 & \text { Very }\end{array}$

Valid

Valid

B. The suitability of worksheet, materials, models and learning objectives

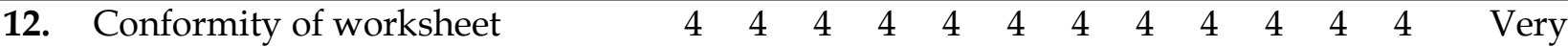
presented with basic

Valid competencies

13. The conformity of the worksheet $\quad \begin{array}{llllllllllllll} & 4 & 4 & 4 & 4 & 4 & 4 & 4 & 4 & 4 & 4 & 4 & 4 & \text { Very }\end{array}$ presented with the indicators in the lesson planning plan

14. The suitability of the worksheet $\quad \begin{array}{llllllllllllll} & 4 & 4 & 4 & 4 & 4 & 4 & 4 & 4 & 4 & 4 & 4 & 4 & \text { Very }\end{array}$ presented with the learning

Valid 
Development of Learning Tools Based on Mind Mapping Worksheet for Improving Stundents' Creative Thinking Skills on Cell Material

\begin{tabular}{|c|c|c|c|c|c|c|c|c|c|c|c|c|c|c|}
\hline No. & Aspects of assessment & & & & Wo & & & $g W$ & & & & & & $\overline{\text { Category }}$ \\
\hline 15. & $\begin{array}{l}\text { objectives } \\
\text { The suitability of the worksheet } \\
\text { presented with the learning } \\
\text { materials }\end{array}$ & 4 & 4 & 4 & 4 & 4 & 4 & 4 & 4 & 4 & 4 & 4 & 4 & $\begin{array}{l}\text { Very } \\
\text { Valid }\end{array}$ \\
\hline 16. & $\begin{array}{l}\text { The suitability of learning } \\
\text { materials with basic competencies }\end{array}$ & 4 & 4 & 4 & 4 & 4 & 4 & 4 & 4 & 4 & 4 & 4 & 4 & $\begin{array}{l}\text { Very } \\
\text { Valid }\end{array}$ \\
\hline 17. & $\begin{array}{l}\text { Suitability of learning materials } \\
\text { with indicators }\end{array}$ & 4 & 4 & 4 & 4 & 4 & 4 & 4 & 4 & 4 & 4 & 4 & 4 & $\begin{array}{l}\text { Very } \\
\text { Valid }\end{array}$ \\
\hline 18. & $\begin{array}{l}\text { Suitability of learning materials } \\
\text { with learning objectives }\end{array}$ & 4 & 4 & 4 & 4 & 4 & 4 & 4 & 4 & 4 & 4 & 4 & 4 & $\begin{array}{l}\text { Very } \\
\text { Valid }\end{array}$ \\
\hline 19. & $\begin{array}{l}\text { The suitability of the learning } \\
\text { material with the learning model }\end{array}$ & 3 & 4 & 4 & 3 & 4 & 4 & 4 & 4 & 4 & 3 & 4 & 4 & $\begin{array}{l}\text { Very } \\
\text { Valid }\end{array}$ \\
\hline 20. & $\begin{array}{l}\text { The suitability of the learning } \\
\text { model with the learning } \\
\text { objectives }\end{array}$ & 3 & 4 & 4 & 3 & 4 & 4 & 4 & 4 & 4 & 3 & 4 & 4 & $\begin{array}{l}\text { Very } \\
\text { Valid }\end{array}$ \\
\hline 21. & $\begin{array}{l}\text { The suitability of the learning } \\
\text { model with learning activities }\end{array}$ & 4 & 4 & 4 & 4 & 4 & 4 & 4 & 4 & 4 & 4 & 4 & 4 & $\begin{array}{l}\text { Very } \\
\text { Valid }\end{array}$ \\
\hline 22. & $\begin{array}{l}\text { Suitability of learning activities } \\
\text { with basic competencies }\end{array}$ & 4 & 4 & 4 & 4 & 4 & 4 & 4 & 4 & 4 & 4 & 4 & 4 & $\begin{array}{l}\text { Very } \\
\text { Valid }\end{array}$ \\
\hline 23. & $\begin{array}{l}\text { Conformity of learning activities } \\
\text { with indicators }\end{array}$ & 4 & 4 & 4 & 4 & 4 & 4 & 4 & 4 & 4 & 4 & 4 & 4 & $\begin{array}{l}\text { Very } \\
\text { Valid }\end{array}$ \\
\hline 24. & $\begin{array}{l}\text { Suitability of learning activities } \\
\text { with learning objectives }\end{array}$ & 4 & 4 & 4 & 4 & 4 & 4 & 4 & 4 & 4 & 4 & 4 & 4 & $\begin{array}{l}\text { Very } \\
\text { Valid }\end{array}$ \\
\hline
\end{tabular}

\section{Requirements disabled}

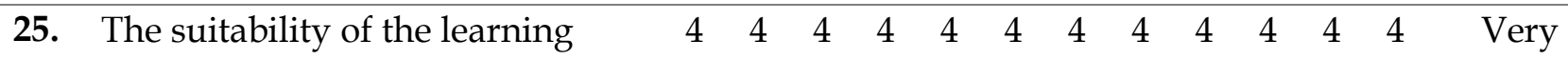
process oriented to active learners $\quad$ Valid

26. There is a stimulus through $\quad \begin{array}{llllllllllllll} & 4 & 4 & 4 & 4 & 4 & 4 & 4 & 4 & 4 & 4 & 4 & 4 & \text { Very }\end{array}$ reading, pictures presented or

Valid activities carried out by students

27. Develop communication, social, $\quad \begin{array}{rlllllllllllll} & 3 & 4 & 4 & 3 & 4 & 4 & 4 & 3 & 4 & 4 & 4 & 4 & \text { Very }\end{array}$ emotional, moral and aesthetic $\quad$ Valid skills as well as learning experiences

28. Develop mind mapping skills $\quad \begin{array}{llllllllllllll}\text { Very } & 4 & 4 & 4 & 4 & 4 & 4 & 4 & 4 & 4 & 4 & 4 & 4 & \text { Ver }\end{array}$

Valid

\section{A. Content eligibility}

29. Content/material truth

$\begin{array}{lllllllllllll}4 & 4 & 4 & 4 & 4 & 4 & 4 & 4 & 4 & 4 & 4 & 4 & \text { Very }\end{array}$

30. It is an essential material

$\begin{array}{lllllllllllll}4 & 4 & 4 & 4 & 4 & 4 & 4 & 4 & 4 & 4 & 4 & 4 & \text { Very }\end{array}$

31. Grouped into logical sections

$\begin{array}{lllllllllllll}4 & 4 & 4 & 4 & 4 & 4 & 4 & 4 & 4 & 4 & 4 & 4 & \text { Very }\end{array}$

32. Its role is to encourage students to think creatively (Fluency)

33 Its role is to encourage students to think creatively (Flexibility)

Valid $\begin{array}{lllllllllllll}4 & 4 & 4 & 4 & 4 & 4 & 4 & 4 & 4 & 4 & 4 & 4 & \text { Very }\end{array}$ Valid $\begin{array}{lllllllllllll}4 & 4 & 4 & 4 & 4 & 4 & 4 & 4 & 4 & 4 & 4 & 4 & \text { Very }\end{array}$ Valid 34. Its role is to encourage students $\quad \begin{array}{llllllllllllll} & 4 & 4 & 4 & 4 & 4 & 4 & 4 & 4 & 4 & 4 & 4 & 4 & \text { Very }\end{array}$ 
Development of Learning Tools Based on Mind Mapping Worksheet for Improving Stundents' Creative Thinking Skills on Cell Material

\begin{tabular}{|c|c|c|c|c|c|c|c|c|c|c|c|c|c|c|}
\hline No. & Aspects of assessment & \multicolumn{12}{|c|}{ Mind Mapping Worksheet } & \multirow{2}{*}{$\begin{array}{c}\text { Category } \\
\text { Valid } \\
\text { Very } \\
\text { Valid }\end{array}$} \\
\hline 35. & $\begin{array}{l}\text { Its role is to encourage students } \\
\text { to think creatively (Elaboration) }\end{array}$ & 4 & 4 & 4 & 4 & 4 & 4 & 4 & 4 & 4 & 4 & 4 & 4 & \\
\hline B & Language truth & & & & & & & & & & & & & \\
\hline 36. & Grammatical correctness & 3 & 3 & 3 & 3 & 3 & 3 & 3 & 3 & 3 & 3 & 3 & 3 & Valid \\
\hline 37. & $\begin{array}{l}\text { The suitability of the sentence } \\
\text { with the level of thinking and } \\
\text { reading ability as well as the age } \\
\text { of the students }\end{array}$ & 3 & 4 & 3 & 3 & 4 & 3 & 3 & 4 & 3 & 3 & 4 & 3 & Valid \\
\hline 38. & Simplicity of sentence structure & 3 & 3 & 3 & 3 & 3 & 3 & 3 & 3 & 3 & 3 & 3 & 3 & Valid \\
\hline 39. & $\begin{array}{l}\text { Sentences don't have double } \\
\text { meanings }\end{array}$ & 3 & 4 & 3 & 3 & 4 & 3 & 3 & 4 & 3 & 3 & 4 & 3 & Valid \\
\hline 40. & $\begin{array}{l}\text { Clarity of instructions and } \\
\text { directions }\end{array}$ & 3 & 4 & 3 & 3 & 4 & 3 & 3 & 4 & 3 & 3 & 4 & 3 & Valid \\
\hline 41. & $\begin{array}{l}\text { The language used is } \\
\text { communicative }\end{array}$ & 3 & 4 & 3 & 3 & 4 & 3 & 3 & 4 & 3 & 3 & 4 & 3 & Valid \\
\hline $\mathrm{C}$ & Technical requirements & & & & & & & & & & & & & \\
\hline 42. & $\begin{array}{l}\text { The questions in the LKPD } \\
\text { presented are no more than } 10 \\
\text { words in one sentence }\end{array}$ & 3 & 3 & 3 & 3 & 3 & 3 & 3 & 3 & 3 & 3 & 3 & 3 & Valid \\
\hline 43. & $\begin{array}{l}\text { The identity of the picture, table } \\
\text { or as a stimulus is clear }\end{array}$ & 3 & 4 & 4 & 3 & 4 & 4 & 3 & 4 & 4 & 3 & 4 & 4 & $\begin{array}{l}\text { Very } \\
\text { Valid }\end{array}$ \\
\hline 44. & $\begin{array}{l}\text { There is a difference between the } \\
\text { questions and answers of LKPD } \\
\text { users }\end{array}$ & 4 & 4 & 4 & 4 & 4 & 4 & 4 & 4 & 4 & 4 & 4 & 4 & $\begin{array}{l}\text { Very } \\
\text { Valid }\end{array}$ \\
\hline 45. & $\begin{array}{l}\text { Clarity of instructions and } \\
\text { directions }\end{array}$ & 4 & 4 & 4 & 4 & 4 & 4 & 4 & 4 & 4 & 4 & 4 & 4 & $\begin{array}{l}\text { Very } \\
\text { Valid }\end{array}$ \\
\hline 46. & $\begin{array}{l}\text { The images or readings presented } \\
\text { convey messages effectively to } \\
\text { LKPD users }\end{array}$ & 3 & 4 & 4 & 3 & 4 & 4 & 3 & 4 & 4 & 3 & 4 & 4 & $\begin{array}{l}\text { Very } \\
\text { Valid }\end{array}$ \\
\hline 47. & There is a bibliography reference & 3 & 4 & 4 & 3 & 4 & 4 & 3 & 4 & 4 & 3 & 4 & 4 & $\begin{array}{l}\text { Very } \\
\text { Valid }\end{array}$ \\
\hline 48. & $\begin{array}{l}\text { LKPD attracts users to carry out } \\
\text { the activities contained in it }\end{array}$ & 3 & 4 & 4 & 3 & 4 & 4 & 3 & 4 & 4 & 3 & 4 & 4 & $\begin{array}{l}\text { Very } \\
\text { Valid }\end{array}$ \\
\hline & prksh & & & & & & & & & & & & & $\begin{array}{l}\text { Very } \\
\text { Valid }\end{array}$ \\
\hline
\end{tabular}

Description;

$\mathrm{V} 1, \mathrm{~V} 2, \mathrm{~V} 3$ = Validator

Based on Table 6 the results of the validity of the mind mapping worksheet based on formative, didactic and technical feasibility aspects have a mode score of 4 with a very valid category. The developed mind mapping worksheet fulfills the formative requirements, which includes completeness of identity, includes KI and KD, clarity of indicators and objectives, compatibility between worksheet, materials and lesson plans. To fulfill the didactic requirements, the worksheet developed includes, among others, a stimulus through reading, pictures presented or activities carried out by students, 
Development of Learning Tools Based on Mind Mapping Worksheet for Improving Stundents' Creative Thinking Skills on Cell Material

developing active students, communication skills, social, emotional, moral and aesthetic, containing learning experiences in the form of mind mapping skills, contains the feasibility of the content, the truth of the content / material, contains questions that encourage students to think creatively. The use of correct, communicative, clear and meaningful grammar is not ambiguous and in accordance with the level of thinking of the age of the students.

The developed worksheet also meets the technical requirements, namely the writing of questions in the worksheet which is presented in no more than 10 words in one sentence, contains clarity of the identity of pictures, tables or as stimuli and instructions, there is a distinction between question and answer sentences, pictures or readings presented convey message effectively, there is a reference to the bibliography and attracts users to carry out the activities contained in it. The development of worksheet is in accordance with the provisions of the National Education Standards Agency (2006), that the LKDP is developed based on aspects of content feasibility, linguistic aspects, presentation aspects, and graphic aspects containing typographical indicators that facilitate reading comprehension and are attractive, appearance design, color composition, elements of clarifying functions and illustrations are able to clarify and facilitate understanding.

In addition to meeting the formative, didactic and technical requirements, the preparation of the worksheet is based on the study and deepening of cell material that is adjusted to the indicators of creative thinking skills. The four types of worksheet developed are as follows; (1) worksheet 1 contains an example of making a mind mapping of plant structures along with the steps for making a mind map, as well as training creative thinking skills to determine the main idea, main sub-ideas and keywords from cell readings (fluency) to prepare for mind mapping. (2) worksheet 2 trains creative thinking skills to analyze (flexibility), provide arguments (originality) from articles, case study readings and pictures of natural phenomena or cell problems. (3) worksheet 3 students are trained to think creatively in analyzing (flexibility) and giving conclusions (fluency, flexibility and elaborating) based on observations of diffusion and osmosis symptoms. (4) worksheet 4 students are trained to organize main ideas, main sub ideas, keywords in LKPD 1 and important words in answers to worksheet 2 and worksheet 3 , to then arrange them in the form of a mind map of cells based on the steps to make a mind map. This is in line with the research of Susanti et al (2018), that students are given the opportunity to think creatively through mind mapping. connects branches and threads in all directions, unique in making color combinations and images and details in creating color combinations. Giving practice questions in the form of mind mapping worksheet as a stimulus, and response responses will train students to face problems and encourage students to respond to creative thinking quickly according to their learning experiences. This is in accordance with Ternodike's theory that, the more often a behavior is repeated and trained, the stronger the stimulus-response association will be. This activity is also correlated with Hergenhahn and Matthew (2008), Information processing theory, information in working memory needs to be organized, linked with other information and repeated to maintain it. mind mapping worksheet 
Development of Learning Tools Based on Mind Mapping Worksheet for Improving Stundents' Creative Thinking Skills on Cell Material

contains open-ended questions based on thinking indicators (1) prior knowledge, reading activities for cell material, determining main ideas, main sub-ideas and keywords in mind mapping worksheet 1 reading (creative thinking skills; fluency), (2) short-term memory (short term memory), students' activities to answer the cell problems that are stimulated in mind mapping worksheet 2 and 3 based on creative thinking skills, flexibility and originality, (3) long-term memory, student activities make mind mapping by recalling the learning experience there are mind mapping worksheet 1 , 2 and 3. Students store as much information as possible, provide easy and direct access to all the information they want, organize it and then arrange it into an original, unique and unique cell mind map. different even for the same material. This is as stated by Windura (2016) that the diversity of mind map results shows the mindset of each student, the emission of thoughts resulting from thought associations that arise from a center of mind.

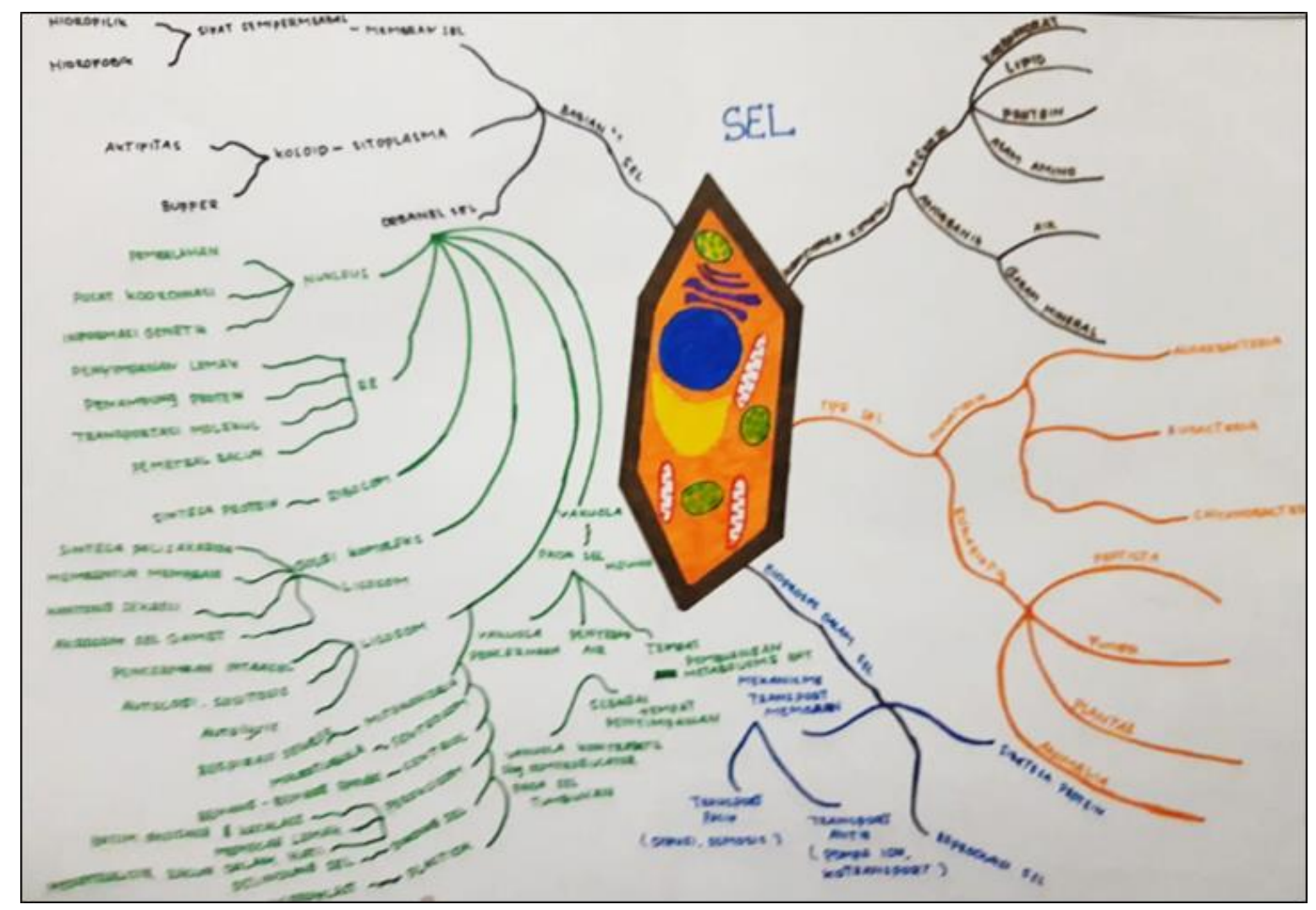

Figure 2. Results of student cell mind map.

The pretest value shows the students' initial ability obtain individual mastery low, then given treat mind mapping worksheet four times a meeting and then given a posttest. Based on the average N-Gain value, the average posttest results are categorized as high, it's just that there are some students who get he N-Gain value in the medium category. The results of the recapitulation of the achievement of creative thinking skills on 10 questions of cell material presented in Table 7 below 
Development of Learning Tools Based on Mind Mapping Worksheet for Improving Stundents' Creative Thinking Skills on Cell Material

\begin{tabular}{ccccc}
\hline \multicolumn{5}{c}{ Table 7. The results of the students' pretest and posttest. } \\
\hline Learners & Pretest & Postest & N-Gain Rate & Criteria \\
\hline 1 & 20 & 87,5 & 0,84 & High \\
2 & 27,5 & 87,5 & 0,83 & High \\
3 & 20 & 82,5 & 0,78 & High \\
4 & 32,5 & 90 & 0,85 & High \\
5 & 37,5 & 87,5 & 0,80 & High \\
6 & 40 & 87,5 & 0,79 & High \\
7 & 35 & 80 & 0,69 & Medium \\
8 & 27,5 & 87,5 & 0,83 & High \\
9 & 42,5 & 92,5 & 0,87 & High \\
10 & 37,5 & 87,5 & 0,80 & High \\
11 & 47,5 & 90 & 0,81 & High \\
12 & 37,5 & 90 & 0,84 & High \\
13 & 30 & 85 & 0,79 & High \\
14 & 25 & 90 & 0,87 & High \\
15 & 35 & 90 & 0,85 & High \\
16 & 32,5 & 90 & 0,85 & High \\
17 & 37,5 & 95 & 0,92 & High \\
18 & 17,5 & 85 & 0,82 & High \\
19 & 25 & 90 & 0,87 & High \\
20 & 15 & 70 & 0,65 & Medium \\
21 & 22,5 & 67,5 & 0,58 & High \\
22 & 25 & 82,5 & 0,77 & High \\
23 & 40 & 90 & 0,83 & \\
\hline
\end{tabular}

Based on Table 7 the results of the learning evaluation of the twenty-three learners experienced a very significant increase in value, with an $\mathrm{N}$-gain ranging from 0.58 to 0.92 with a completeness of 86.3. During the learners learning process, completing the mind mapping worksheet containing openeded questions containing indicators of fluency, flexibility, originality and elaborating, making students trained to deal with problems and encouraging students to respond to creative thinking quickly according to their learning experience, so they are able to to solve problems with a similar technique when given an evaluation test. The activity of compiling a mind mapping through the steps of determining the main idea, determining the main sub-ideas, determining keywords to support the main idea, making branching as a link and providing details to clarify the reader as well as rewriting their understanding of the cell concept they are learning, make participants learn more about the concept. Mind mapping activities both individually and in groups require students to be able to understand and remember the material they read, then express it in writing (Muslimin, 2019). The use of mind map media will make it easier for students to understand topics with high conceptual complexity (Dewi, 2019). Some learners still have a medium in practicing mind mapping worksheet during learning have not shown creative thinking skills, and the results of the mind map cells made are not in accordance with the correct instructions. This is due to several factors, among others; differences in developmental 
patterns that are not the same in both ways of thinking and behaving in solving problems. The social and emotional development of students is a unique and permanent difference that is influenced by heredity and the environment (Surna and Olga, 2014). The incompleteness of students is also due to the factor of creative thinking skills which are high-level cognitive scales including C4, C5 and C6, as the results of research by Susantini et al (2016), states that creative training must include evaluation instruments that involves higher levels of thinking, including creative thinking skills. Based on the results of interviews with teachers and learners in the pre-research, so far in the pilot school they have never trained creative thinking questions and made mind mapping in learning, so some students need more time to explore their creative thinking skills. Figure 3 below presents the achievement of creative thinking indicator skills;

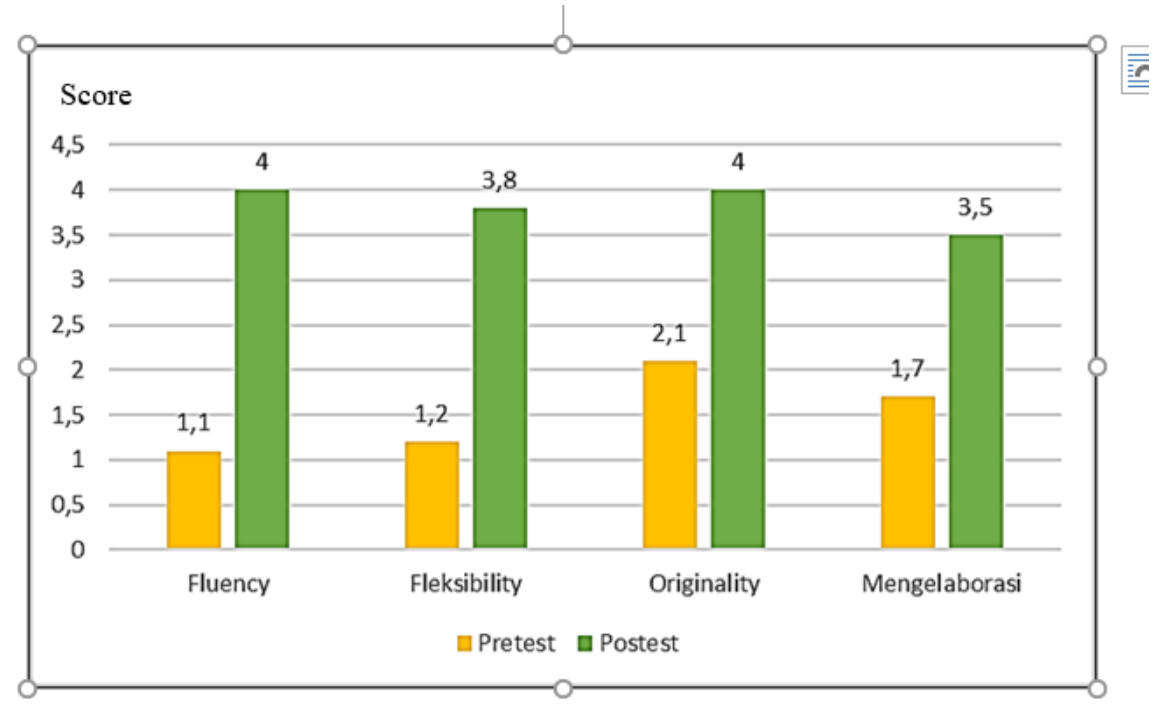

Figure 3. Graph of learners' creative thinking skills during the trial.

The fluency indicator has an N-gain of 0.86 in the high category, it can be seen in how the participants interpret the relationship between the characteristics of the cell membrane constituents and the permeability properties (question no. 2) and are able to describe the organelles that play a role in protein synthesis (question no. 6) from reading articles which is simulated in the problem. Fluent thinking behavior is being able to answer several answers if there are questions, asking many questions, expressing opinions to express many ideas / ideas related to a problem, and working harder. The indicator of flexibility with N-gain in this aspect looks 0.92 , it can be seen in the students' skills in making hypotheses about organisms that have the highest adaptation based on the presence or absence of membrane structures (question no. 1), concluding cell organelles that play a role in overcoming the toxic effects of $\mathrm{H}_{2} \mathrm{O}_{2}$ (question no. 3), hypothesized the dysfunction of cell organelles causing Pompe's disease (question no. 4), and hypothesized the number of mitochondria based on differences in the activity of several body muscle cells (question no. 8). This is because students through the learning experience using mind mapping worksheet train their ability to analyze and solve problems. Open-ended questions with (divergent) thinking will give a person the opportunity to give more than one and different correct answers 
Development of Learning Tools Based on Mind Mapping Worksheet for Improving Stundents' Creative Thinking Skills on Cell Material

so as to encourage flexible thinking (Buzan, 2018). Originality indicator, seen in students' skills in comparing the types of cytoskeleton constituents (question no. 7) and providing an argument against a case study if plants were given excessive amounts of fertilizer (question no. 10), has an N-Gain with a range of 0.83 high category. Mind mapping worksheets contain open-ended questions to train students to give many answers (fluency) and analyze pictures/stories in solving cell problems that are simulated in mind mapping worksheets (flexibility) which indirectly stimulate students to develop originality creative thinking skills. Students' skills can be seen in how they practice interpreting arguments against a problem, analyzing an object or story related to cells, analyzing the results of the diffusion and osmosis symptoms practicum and making conclusions so that indirectly the three aspects complement each other. This is in accordance with Arulselvi's report (2017), which states that originality will emerge if the teacher develops fluency and flexibility through question and answer activities or discussions. Elaborating skills, having an N-gain of 0.86, shows the students' skills to compare the types of cytoskeleton constituents (question no. 7) and detail the dissolution process (question no. 9). Mind mapping worksheet 4 trains students to make cell mind maps, in this activity students train their cognitive development to interpret their understanding of the cell concept, visualize and communicate it through detailed images so that it can be understood. This is in line with research of Widiana and Jampel (2016) that, the teaching process through providing opportunities for students to present their abilities based on the material studied then followed by a review of the concepts studied will strengthen the concepts they have constructed themselves from the first stage.

The results of the parametric statistical tests of normality, homogeneity and the effect of the application of mind mapping worksheets in learning based on the results of the pretest and posttest are presented in Table 8 below

Table 8. Pretest and posttest parametric statistical test result.

\begin{tabular}{|c|c|c|c|}
\hline Test & A & Sig & Description \\
\hline Normalitas & 0,05 & 0,2 & Normal \\
\hline Hemogenitas & 0,05 & 0,032 & Homogen \\
\hline Paired t-test & 0,05 & 0 & There is a significant difference \\
\hline
\end{tabular}

Based on the results of the Kolmogorov Smirnov test, it was obtained that sig > , meaning that the data came from a normally distributed population. This means that the state of the sample taken is similar to the actual population. Based on the results of Levene's test, it is obtained that sig $>$, meaning that the data comes from a homogeneous population variance. Based on the test results, it shows that all students have the same knowledge ability at the beginning of learning. Based on the results of paired t-test, it is obtained that sig $<$, means that the average pretest and posttest results are significant difference (Sugiyono, 2014).

Student Worksheets (LKS) as part of teaching resources can foster students to generate their own thoughts, ask questions, make connections, evaluate results, so that student autonomy increases as well (Chappell and Craft in Susantini et al (2016)) The application of mind mapping can stimulate students' imagination to facilitate them in 
Development of Learning Tools Based on Mind Mapping Worksheet for Improving Stundents' Creative Thinking Skills on Cell Material

expressing the concepts/ideas in their minds and the production of mind mapping proves that students understand the interconnection of the concepts studied (Widiana and Jampel, 2016).

\section{CONCLUSION}

The development of a mind mapping worksheet-based device was declared feasible (valid, practical, and effective) to train students' creative thinking skills in class XI MIPA on cell material. Based on the results of the limited trial conducted, it is necessary to provide an explanation of mind mapping before the mind mapping worksheet is applied in learning with an appropriate time allocation. Learning that has enough material should use mind mapping to summarize and strengthen memory and make it easier for students to understand the material being studied.

\section{ACKNOWLEDGEMENTS}

The researcher would like to thank lecturer Dr. Isna, M.Si. and Dr.sc.agr.Yuni Sri Rahayu, M.Sc, as validators who have provided corrections and suggestions for this learning tools on mind mapping worksheet and students of class XI MIPA AL-Islam Krian senior high school who have been willing to help this research.

\section{REFERENCES}

Arulselvi, E. (2017). Mind maps in classroom teaching and learning. The Excellence in Education Journal, 6(2), 50-65.

Buzan, T. (2018). Mind map mastery the complete guide to learninng and using the most powerful thinking tool in the universe. Watkins

Dewi, A. K. (2019). Improving students learning outcomes through mind map in human reproductive system topic in natural science learning. International Journal for Educational and Vocational Studies, 1(7), 702-706. https://doi.org/10.29103/ijevs.v1i7.167

Eratay, E. (2017). An investigation on the creativity of turkish fine arts high school students: a case study. Journal for the Education of Gifted Young Scientists, 5(2), 55-70. https://doi.org/10.17478/JEGYS.2017.56

Erdem, A. (2017). Mind maps as a lifelong learning tool. Universal Journal of Educational Research, 5(12A), 1-7. https://doi.org/10.13189/ujer.2017.051301

Hake, R, R. (1999). Analyzing change/gain scores. AREA-D American Education Research Association's Devision, Measurement and Reasearch Methodology.

Heni, V., Hilarius, J. D., \& Markus, I. S. (2017). Penerapan metode student facilitator and explaining berbantukan media peta timbul terhadap kemampuan berfikir kritis siswa pada materi sel. Jurnal Pendidikan Biologi, 2(2), 20-26. https://doi.org/10.31932/jpbio.v2i2.221

Hergenhahn, B. R., \& Matthew H. O. (2008). Theories of learning (teori belajar). Jakarta: Prenada Media Group

Yeong, F. M. (2013). Incorporating mind map in cell biology lecturea_a. reflectionon the advantages and potential drawback. Jurnal of Prodecia 103(1), 485-491. https://doi.org/10.1016/j.sbspro.2013.10.364

Marshel, J., Ratnawulan, \& Ahmad, F. (2020). Practicality of student worksheets science based on problem based learning models with the theme of the motion in life using integrated connected type 21st century learning. Journal of Physics: Conference Series, 1876(1), 1-9. https://doi.org/10.1088/1742-6596/1876/1/012050 
Development of Learning Tools Based on Mind Mapping Worksheet for Improving Stundents' Creative Thinking Skills on Cell Material

Muslimin, A. (2019). Reading, mind mapping, and sharing (RMS): Innovation of new learning model on science lecture to improve understanding concepts. Journal for the Education of Gifted Young Scientists, 7(2), 323-340. http:/ / dx.doi.org/10.17478/jegys.570501

Polat, O., Ezgi, A. Y., \& Ayse, B. O. (2017). The effect of using mind maps on the development of maths and science skills. Cypriot Journal of Educational Sciences, 5(1), 32-45. http://doi.org/10.18844/cjes.v12i1.1201

Riduwan. (2013). Skala pengukuran variabel-variabel penelitian. Bandung: Alfabeta.

Santoso S. (2014). Statistik parametrik konsep dan aplikasi dengan SPSS. Jakarta: PT Elex Media Komputindo.

Setyawan, U. R. (2013). Pengembangan lembar kegiatan peserta didik berbasis mind mapping untuk melatihkan keterampilan berfikir kreatif pada materi pertumbuhan dan perkecambahan tumbuhan kelas XII SMA. Skripsi. Surabaya: UNESA

Sugiyono, (2018). Metode penelitian kuantitatif kualitatif dan RED. Bandung: Alfa beta

Surna, I. N., \& Olga, D. P. (2014). Psikologi pendidikan. Jakarta: Erlangga

Susanti, L. B., Poedjiastoeti, S., \& Taufikurohmah, T. (2018). Validity of worksheet-based guided inquiry and mind mapping for training students' creative thinking skills. Journal of Physics: Conference Series, 1006(1), 1-7. http:/ / doi.org/10.1088/1742-6596/1006/1/012015

Susantini, E., Isnawati., \& Lisa, L. (2016). Effectiveness of genetics student worksheet to improve creative thinking skills of teacher candidate students. Journal of Science Education, 2(17), 74-79.

Widiana, I. W., \& Jampel, I. N. (2016). Improving students' creative thinking and achievement through the implementation of multiple intelligence approach with mind mapping. International Journal of Evaluation and Research in Education (IJERE), 5(3), 246-254. http:// doi.org/10.11591/ijere.v5i3.4546

Windura, S. (2016). Mind map langkah demi langkah. Jakarta. Gramedia

\footnotetext{
*Ainul Badriyah (Corresponding Author)

Universitas Negeri Surabaya,

Postgraduate Programme, Science Education Study Program

Continuing Program Development, Jl. Unesa Lidah Wetan, Surabaya, East Java, Indonesia.

Email: ainul.19018@mhs.unesa.ac.id

Prof. Dr. Sri Poedjiastoeti, M.Si.

Universitas Negeri Surabaya,

Postgraduate Programme, Science Education Study Program

Continuing Program Development, Jl. Unesa Lidah Wetan, Surabaya, East Java, Indonesia.

Email: sripoedjiastoeti@unesa.ac.id

Dr. Yuliani, M.Si.

Universitas Negeri Surabaya,

Postgraduate Programme, Science Education Study Program

Continuing Program Development, Jl. Unesa Lidah Wetan, Surabaya, East Java, Indonesia.

Email: yuliani@unesa.ac.id
} 